\title{
Quality of Work Life Dimensions in Universities: A Systematic Review
}

\author{
Bethuel Sibongiseni Ngcamu ${ }^{1}$ \\ ${ }^{1}$ Durban University of Technology (DUT), Durban, South Africa \\ Correspondence: Bethuel Sibongiseni Ngcamu, Department of Public Management and Economics, Durban, \\ South Africa. E-mail: ngcamub@webmail.co.za
}

\author{
Received: June 7, 2017 Accepted: August 21, 2017 Online Published: September 6, 2017 \\ doi:10.5539/gjhs.v9n10p118 URL: https://doi.org/10.5539/gjhs.v9n10p118
}

\begin{abstract}
Quality of Work Life (QoWL) is topical in universities in this epoch of managerialism which has directly influenced workplace environments. However, most of the extant research has focussed on the developing relationship between QoWL and job satisfaction of academic (teaching) staff members. To date, few attempts have been made at reviewing the literature pertaining to QoWL as a concept, its dimensions and impact on the diverse aspect of employees. This study adopts an interpretive framework as a philosophical perspective and follows a hermeneutic framework as the literature obtained from databases will be classified, mapped, critically assessed and arguments developed. The current study is a unique attempt to review the literature on QoWL concepts, dimensions and gaps commencing from its inception in the 1970s. There is a dearth of literature-based review studies on the impacts of QoWL in universities which this study attempts to fill.
\end{abstract}

Keywords: hermeneutic framework, literature review, universities, work-home interface

\section{Introduction}

Quality of Work Life (QoWL) literature has grown substantially in universities globally with multi-dimensional perspectives and concepts being coined. This has been noticeable in studies conducted at different universities investigating relationships between QoWL and career development (Idris, Samah, Wahat \& Parsa, 2014), with job satisfaction (Kermansarvis, Navidian, Rigi \& Yaghoubinia, 2014), with organisational commitment (Daud, 2012), Shahbazi Shokrzadeh, Bejani, Malekinia \& Ghoroneh, (2011) undertaking a research study on the QoWL and performance and productivity at Iranian universities (Mohammad, Ahmad \& Reza, 2013). Furthermore, a comparison between the QoWL for professors in a developing country (Brazil) and a developed country, Canada (Boas \& Morin, 2013), comparison between existing and expected QoWL in universities (Kumar \& Shanubhohue, 1996), QoWL among teaching staff of university of Tehran (Mirkamalia \& Thanib, 2011), investigating organisational pressure on QoWL and women in administration at a university (Ogunsanya, 2012) has also been scantly explored. Limited literature studies have been conducted, however most extant research has focussed on the QoWL for academic employees (Pandey \& Jha, 2014) and the research study devoted to non-academic staff QoWL (Johnsrud, 2012). Some commentators (Pandey \& Jha, 2014; WFD Consulting, 2003) have pointed out that research has been conducted to measure the QoWL of other sectors with the exception of universities, which is a troubling sign about QoWL in these institutions with long-term repercussions for student teaching and learning, socio-economic quality and growth rate.

Against this backdrop outlined, this literature review study intends to close this vacuum in the QoWL in three ways. Firstly, to critically classify, map and assess available literature on QoWL in both developing and developed countries by using a hermeneutic framework (Boel \& Kecmanavic, 2014). Secondly, to study QoWL definitions and dimensions prevailing in universities and, thirdly, to ascertain gaps in the literature for future research in QoWL in the context of universities.

What follows next is the conceptual evolution of the QoWL and its dimensions between the eighteenth and twenty-first century, followed by empirical studies conducted on QoWL. This literature review study concludes by discussing a research agenda on QoWL as well as providing conclusions, limitations and suggestions for future researchers.

\section{The Evolution of the QoWL: A Conceptual Research Agenda}

There is a paucity of published scholarly literature on the QoWL focussing on all job categories, including academic, academic support, administration and technical services, at universities. However, there is a plethora of 
scholarly articles on the QoWL published in different journals (including on business management, social sciences and higher education) mainly focussing on academic staff members with very few focussing on administrative members. QoWL in the 1960s focussed on the employees' psychology and their views of the workplace situation (Reyan, 1995). According to Mirkamalia and Thanib (2011:180), QoWL was invented in the 1970s from social and technical system to ensure that there is independence, interdependence and self-involvement in organisations. Davis and Cherms (1975) argue that the concept QoWL was introduced by Louis Davis in 1972 as a field of study in work design which was termed Socio-Technical System Design. QoWL is multifaceted which encapsulates daily life of employees at work including an organisation's awareness of its role, positions and employee working conditions which are beneficial for the economic viability of the organisation. According to Pandey and Jha (2014:2), QoWL is coined as a human resource term utilised to increase employee's worklife. In the previous decades the concept, QoWL has been framed only on personal life while current definitions put an emphasis on the social issue (Mirkamalia \& Sani, 2008).

Several researchers (Idris et al., 2014: 08; Rethinam \& Ismail, 2008; Sirgy et al., 2001) have captured comprehensive concepts of QoWL, including health and safety, social esteem, actualisation, knowledge and aesthetics. The European Foundation for the Improvement of Living Conditions (2002) and Q. P. Singh and K. S. Singh (2015), have related the QoWL with employee satisfaction and involvement at workplace. This is attributed to motivated, productive, healthy and safe employees with job security. In addition, these authors have associated the QoWL with developing competent employees and that there is a worklife interface. Serey (2006), Panday and Jha (2014) and Walton (1973) suggested that QoWL should enhance job meaningfulness and needs satisfaction. Consequently, Panday and Jha (2014) mentioned a balance between professional, personal and social life, while Walton (1973) emphasises employee satisfaction and psychological needs as central to QoWL. Meanwhile, other researchers (Hackman \& Oldham, 1980; Khorsadi et al., 2010; Yavari et al., 2009) cite concepts that are associated with QoWL as interwoven into both psychological and physical appeal of the workplace and employee situations, with Khoarsadi et al. (2010) further citing health, economic and personal beliefs. It is worth noting that concepts captured in the early 1990s included job security, better financial and non-financial rewards, higher salaries, more opportunities for growth and participation in groups (Havlavic, 1991), psychological distress and well-being, high organisation commitment and health as well as the Work Life Balance (WLB) (Ketchum \& Trist, 1992). In the 1980s, researchers linked QoWL to work environment and personal needs (Hachman \& Oldham, 1980), to job characteristics and work conditions (Lawler, 1982) and employees shaping their positions according to their options, interests and needs (Beukema, 1987). In the broader literature, researchers have different perspectives in their definitions of QoWL. While endless variables of the QoWL have been mentioned, most authors agree on their conceptualisation of QoWL as referring to the health and safety of employees (Idris et al., 2014; Khoarsadi et al., 2010; Ketchum \& Trist, 1992); satisfaction (Panday \& Jha, 2014; Walton, 1973) and WLB (Rethinam, 2008; Ketchum \& Trist, 1992).

\section{QoWL Dimensions between Eighteenth and Twenty-First Centuries}

Mirkamalia \& Thanib (2011:180) argue that the QoWL has multi-perspectival structure which is made up of terms such as securing jobs for employees, compensation systems, workflows, opportunities for skills development and involvement in decision-making. According to Boas and Morin (2013:68), dimensions of QoWL include independence at workplace, ability to exercise judgment, the significance of decisions, prospects for learning, utilisation of skills, performance management criteria, obstacles in the workplace, diverse responsibilities, interpersonal relations, acknowledgement, accomplishment of activities, and job contribution to the realisation of the institutional objectives, participation of employees in decision-making processes. Royuela, Lopez-Tamayo and Surinach (2008) have undertaken a comparative study of the QoWL terms for the university teaching employees and for the European Commission where ten construct were found including inherent value of work, training and development, equality on gender, employee health and safety, inclusivity and accessibility to the labour market, workplace and WLB, social discourse and employees' consultation, diversity and non-discrimination, and performance management. Buffardi, Baughman and Morse (2004) conducted a survey in George Mason University on the task force measuring the QoWL of employees. These researchers found different dimensions including cover remunerations, health and retirement benefits, work security, workspace, acknowledgement for accomplishments, availability of child care in the university, involvement in the decision-making processes and impartial performance management. Buffardi et al., (2004) investigated the employees' perceptions on QoWL at the Razak University, Malaysia, with specific reference to how the university environment affects their satisfaction in the workplace. In this study, Buffardi et al. (2004) used ten QoWL variables (work-life interference, relationship (quality), meaningfulness, distrust about organisational change management, employee capability, influence, employee determination, accessing resources, time management) to examine the associations between QoWL and 
satisfaction of employees at workplace. Serey's (2006) QoWL dimensions include employees usage of the talent and capacity to counteract challenges that require creativity and autonomy, individual involvement on activities, an understanding on the role and responsibilities the individual must play in achieving organisational goals and taking pride if an activity is done well.

According to Ketchum and Trist (1992), QoWL include work meaningfulness, sense of belonging and commitment, self-respect and accomplishment of tasks at workplace and WLB. Casio (1992) alluded that the dimensions of the QoWL consist of employees' participation, job development, resolving conflicts, mode of communication, health and safety, secured employment, fair rewards workplace \& health safety and sense of honour. Johnsrud \& Des Jarlais (1994) mentioned other significant aspects important to the QoWL as including research, administrative, labour and technological support as well as parking for employee cars. A research study by Levine (1983) utilising a Delphi technique to a 70 employees found six measures including managers' confidence and respecting of employees, diversification of responsibilities, employees challenges at workplace, impartial promotions, WLB and self-esteem. Walton developed a model in 1973 for the QoWL which encapsulated adequate compensation, environment that is safe and healthy, constitutionalism at workplace, development opportunities and employment security, social relevance and integration and human capabilities development. However, from the literature reviewed it can be summarised that QoWL is perceived as wide ranging organisational variables, which might have a direct influence on employees' needs.

A review of the literature indicates many different and somewhat similar dimensions of QoWL. Most QoWL studies conducted in universities are in the twenty-first century (Vilas et al., 2013; Royuela et al., 2008; Buffardie et al., 2004; Serey, 2006). While previous authors' studies have mentioned various dimensions central to QoWL, involvement in decisions, use of skills, interaction with colleagues (interpersonal skills), recognition and contribution to the objectives of the institution are commonly mentioned in studies on QoWL in the twenty-first century. Royuela et al. (2008) mentioned overall performance, while Boas and Morin (2013) cited performance criteria as dimensions of QoWL. What is of paramount interest in the literature from the 1970s, when the QoWL was first coined, is that different studies are central to the meaningfulness of work (Ketchum \& Trist, 1992; Buffardie et al., 2004), with the exception of nineteenth and twentieth century studies. Almost all literature reviewed in different centuries except the nineteenth century cited in their QoWL dimensions health and safety at the workplace (Buffardi et al., 2004; Royuela et al., 2008; Casio, 1992; Walton, 1974; Walton, 1975). The literature reviewed also showed the WLB as dominating in different centuries (Royuela, et al., 2008; Kerchum \& Trist, 1992; Levine, 1983).

\section{Empirical Research Studies Conducted on the QoWL}

Between 1980 and 2006 research studies conducted on the QoWL revealed an association between QoWL and organisational variables such as job satisfaction (Armstrong, 2006; Mirkamali \& Sani, 2008). Idris, et al (2014:108) conducted a survey among 307 academic staff members in Iran investigating the correlation between QoWL and career advancement. This study concluded that increased QoWL impact to increased career advancement and educational and societal development. Winter, Sarros and Tanewski (1998) had undertaken a research study to establish current levels of academic QoWL, identify the relative importance of role, job, supervisory, structural and sectoral characteristics to academic QoWL at Australian tertiary institutions. This study findings revealed a positive association of QoWL and increased independence of the teaching staff members, task identity. The results by Winter et al. (1998) showed positive aspects of Australian academics' current job include high levels of autonomy, task identity and job challenges. The previous study also found that employees received poor feedback from managers and experienced work overload. A survey by Boas and Morin (2013:67) assessed QoWL among 354 professors in Brazil (a developing country) and 317 professors in Canada (a first world country). This study found a significant difference in various components of the QoWL including meaningfulness at work, stress, employee commitment and work-life interface. This study by Boas \& Morin (2013:67) also found Brazilian professors to have meaningfulness at work and were more committed than their Canadian counterparts.

Pandey and Jha's (2014:2) conducted a study to review and redefine literature on QoWL which showed that QoWL influences play a pivotal role in promoting a very strong work ethic and culture, human resource environment, inspiring employees to perform their functions and exceed the agreed standards. Pandey \& Jha, 2014) further suggested that universities should promote autonomy and accountability, collaboration with industry, workshops and trainings conducted on new technologies, standards and processes as well as employee exchange programmes with national and international universities. Additionally, the authors suggested that fair and transparent employee evaluation, including rewards and recognition, promotion, life and career advising centres as well as frequent meetings, dialogues and sharing of information should be promoted in universities. 
An analytical study was conducted among 202 employees of Zahedan University of Medical Sciences by Kermansaravi, Navidian, Rigi \& Yaghoubinia (2014) to determine the correlation between employee satisfaction and the QoWL. This study found that the QoWL can be increased by manipulating its dimensions, through financial and non-financial rewards and the involvement of employees in decision-making. A research study conducted by Tabassum (2012) among teaching members in a faculty in Bangladesh revealed a significant relationship between all aspects of the QoWL and employee satisfaction. Another investigation by Ballou, Norman, \& Goodwin (2007) found that satisfied employees who find the work environment conducive are loyal to the organisation thus increasing the efficiency and capita in the organisation. A plethora of studies in different countries such as in Columbia and Iran (Dolan et al., 2008; Mirkamali \& Narenji Sani, 2008; Teymouri, 2008) has shown a strong relationship between knowledge of worklife and employee satisfaction. While a study by Soltanzadeh, Ghalvandy \& Fatah (2012) showed dimensions such as constitutionalism, social relevance of worklife and social integration to have a strong relationship with the employee satisfaction. A perception study undertaken by Daud (2012) among 170 employees at a Malaysian university to determine the relations between the QoWL and organisational commitment amongst the teaching staff members showed the levels of the QoWL to be favourable and organisational commitment moderate. The research findings also revealed that employee participation at workplace influences employee commitment as well as growth and development.

Mohan and Suppareakchaisakul (2014) examined QoWL among university teachers in Thailand and Malaysia with the aim of examining a relationship with selected psychosocial factors of subjective well-being measured in three dimensions including satisfaction at workplace, work family conflict, and general self-efficacy. This study revealed that work-family conflict had a direct negative effect on Subjective Well-Being (SWB) and an indirect effect on QoWL. The QoWL was found to be directly affected by self-efficacy and indirectly affected through subjective well-being. The present findings suggested that improvements to the QoWL for both Thai and Malaysian universities needs to take into consideration psychosocial factors and subjective well-being.

An empirical study by Johnsrud (2002) measuring QoWL of academic and administrative staff members offered a framework that conceptualises studies on QoWL whereby differences were described and explored, the impact of worklife on attitudes was determined, explaining behavioural outcomes and addressing the results for practice and policy. The author posits that university leaders who intend to increase employee performance and retain employees in all job categories must investigate and respond to the employee needs. There is a paucity of published research on administrative staff as compared to that on faculty members (Johnsrud, 2002:388). Shahbazi, et al., (2011) assessed the causal relations between the QoWL and performance of 60 leaders of Esfahan University. This study revealed that QoWL has a significant relationship with performance in regard to developing employee competence, constitutionalism at work place, institution, employee life space and social integration in the work organisation.

This research by Mohammad, Ahmad and Reza (2013) was conducted with the primary objective of ascertaining whether there is a link between QoWL and teaching staff members' productivity in Iranian universities. Walton's QoWL and Hershey and Goldsmith's (achieve Model) Manpower Productivity questionnaires were administered to 224 academic full time male faculty members. It seems that fair and appropriate salary, hygienic and safe workplace, making continuous development and security opportunities, obedience in the organisation, social unity and solidarity in organization and imparting capabilities can contribute to teaching staff member's productivity in a university. Thus, it can be claimed that setting goals for training faculty members of a university and reforming organisational structures in the university can have an effect on their productivity. Mohammad et al (2013) suggested that other similar studies be conducted in other universities with the measurement tools of this research and compared with the acquired results.

Punia and Kamboj (2013: 197) ponder that QoWL augments teachers' effectiveness and satisfaction, wellness and increased the behaviour of students. The study undertaken by Punia and Kamboj (2013) on the QoWL balance amongst Indian teachers found that their designations, nature of appointment and academic stream affect their QoWL balance directly and significantly. A research study conducted by Nanjundeswaraswmy \& Swamy (2013) among 109 employees in a private technical institution to examine the QoWL of employees revealed that male employees were more satisfied than their female counterparts and that adequacy of resources were associated with the QoWL and the training and development less correlated. In terms of the non-teaching staff, compensation and rewards were more correlated and work environment less correlated with the QoWL. Mensah and Lebbaeus (2013) conducted a survey in a Ghanaian university with a purpose to determine employees' self-efficacy and the QoWL as well as the extent to which self-efficacy of employees' influence their QoWL. This study found a positive interconnection between self-efficacy and the QoWL implying that self-efficacy has a direct influence on employees QoWL. The study by Hans et al. (2015) aimed to show the phenomena related to QoWL and 
occupational stress was conducted among lecturers in Oman. The study findings showed that occupational stress negatively affected the QoWL of lecturers. A study by Bhavani and Jegadeeshwaran (2015) to 289 university of Mysore with the aim to understand the relationship between job satisfaction and QoWL of women teachers in a university. This study found a positive impact of job satisfaction on the QoWL of women teachers. A literature review study by Muindi and K'Obonyo (2015) sought to interrogate the employee factors that influence the relationship between QoWL and performance. This study through extensively reviewed literature established that there is a relationship between QoWL and performance and that QoWL programmes are associated with outcomes such as improved employee performance, employee participation and involvement and responsibility. In a study of dimensions of the QoWL as its affects the life and attitude at work of teachers in Pakistani universities by Arif and Ilyas (2013) found different dimensions including importance of work, organisational environment, and WLB and employee satisfaction to have an association with the QoWL. In another study by Farid (2015) investigating the association between QoWL and organisational commitment in a Malaysian university found that there is an inter-correlation between the latter dimensions of the QoWL. The objective of the study by Kaur \& Sharma (2016) was to assess factors the QoWL of teaching workers in a public university in Punjab (India). These authors found that in order for employees to work effectively in a university, salary and rewards, good leave system, flexible working hours and greater opportunities for promotion are essential. However, Kaur and Sharma (2016: 9) also found that factors which include work overload, senior management behaviour, long distance travelling to work and organisational politics resulted in employees performing ineffectively. A study conducted by Zabrodska et al, (2016) to examine the QoWL among the teaching staff in Czech university to assess to what extent marketization affects staff members. The results showed a disproportionately high level of job satisfaction and low level of stress. These authors indicated that the teaching staff revealed positive attributes of their workplace including independence and quality, clarity on the roles and responsibilities, strong social community although employees also shed light on their dissatisfaction on salaries, weak leadership and pressure on productivity. A scientific study by Khan, Ara, and Bhat (2016) examining parameters regarding the QoWL among the teaching staff in universities in India. This study was framed to two parameters including work and total space and social relevance. The research findings found no significant difference between the QoWL and the dimensions mentioned above.

A research study among 150 faculty academic members was conducted by Mirkamalia and Thanib (2011) at the University of Tehran (UT) and Sharif University of Technology (SUT) to determine QoWL. Previous authors' findings revealed adverse QoWL conditions in these two previous universities and a small difference in social integrity and cohesiveness amongst employees. A study by Saeed and Farooqi (2014) among 250 women at a university in Nigeria investigated organisational pressure on the QoWL. This study investigated numerous variables including salaries, benefits, and children's day-care services at workplace and employee workload. Saeed and Farooqi (2014)'s research study found no significant difference on women staff members satisfaction and that all dimensions mentioned above had a direct relationship on the QoWL of women. Another study done by Aketch et al. (2012) among Kenyan university academic staff showed that a positive correlation between QoWL and overall performance existed. A study by Ngcamu and Letooane (2015a) investigated the impact of managerialism on the QoWL of employees at a particular university in South Africa. This mixed method study reflected contradictory perceptions on the availability of policies promoting the QoWL of employees, which were available but inconsistently applied and not enforced by university leaders. Another descriptive study by Ngcamu and Letooane (2015b) investigated employee satisfaction at workplace and general wellbeing among university leaders in South Africa, which revealed the majority of employees having clear goals and opportunities for development which was not the case for the majority of the research participants who were depressed and felt that there was a lack of career opportunities in the university. The limitations of these studies reviewed above were on the paucity of published data on the QoWL in South African universities and sampling, which was taken from one previously disadvantaged university.

\section{Towards a Research Agenda}

Extant research suggests that QoWL impacts on satisfying employees in universities (Kermansaravi et al., 2014; Panday \& Jha, 2014; Tarbassum, 2012; Soltanzadeh et al., 2012), with a few on career advancement (Idris et al., 2014). Most of the reviewed literature reflect the fact that studies conducted were descriptive (quantitative) in nature where relationships between QoWL and job satisfaction were made mostly in the Middle East (Iran, Bangladesh and Malaysia). Meanwhile, there are few studies that attempted to compare the QoWL of employees from universities in developed and developing countries (Boas \& Morin, 2013); job categories including academic, non-academic and academic support staff members (Johnsrud, 2002; Saeed \& Farooqi, 2014). It is clear from the literature that published studies on QoWL in universities are case studies, which are based on quantitative research tradition with minimal available studies on literature review using qualitative research methods. The literature 
review study that was reviewed used a desk research which concluded that QoWL impacted on employees performing at maximum level and suggested that QoWL is influenced by both internal and external factors which can increase the QoWL (Pandey \& Jha, 2014).

There are many fascinating developments gleaned from this literature review study on QoWL at universities. As noted, the study on QoWL among university professors in Brazil (developing country) had meaningfulness and showed that the professors were more committed to their university than their Canadian counterparts (Boas \& Morin, 2013). An interesting pattern highlighted in this literature review inquiry was an association that developed between QoWL and performance with a focus on rewards and recognition (Daud, 2012; Kermansaravi et al., 2014; Pandey \& Jha, 2014; Johnsrud, 2002; Shahbazi et al., 2011) and productivity (Mohammad, 2013). Another theme seldom mentioned in QoWL discourse which emerged under the realm of this literature study were the effects of the QoWL on efficiency of the staff members at tertiary institutions (Kermansaravi et al., 2014; Ballou et al. 2007; Johnsrud, 2002).

\section{Conclusion}

This review of the literature on QoWL at universities suggests that QoWL is a multifaceted paradigm built on different disciplines and sub-disciplines that seek to ensure the welfare of employees. It can be deduced from the literature reviewed that QoWL effects have been related to a multiplicity of factors applicable to staff including their satisfaction at work, career advancement, organisational commitment and loyalty, retention of staff, efficiency, career development, increased performance, autonomy, workload and productivity mostly to academic category of employees. It is clear from the literature that comparative studies on QoWL in developed and developing countries as well as on non-academic staff and women are minimal. It is evident from the literature that QoWL, as a concept, has been evolving and orientated into everything in the past decades in an institution with a clear contemporary objective directing it into social issues. QoWL as a concept, is a collection of the entire human resources function, including recruitment and selection, benefits and compensation, skills development, employee relations, health and safety, organisational development and operations, with a common goal ensuring employees are satisfied at work. Accordingly, it can be concluded that QoWL touches on different management levels (operational, tactical and strategic) as well as personal, interpersonal and cognitive abilities to be applied with a clear goal to ensure employees are satisfied and, thus, productive. Furthermore, the literature indicates that QoWL can be increased when employees participate in the university decision-making structures (decentralisation), including all levels of strategic planning and WLB. The review has shown that most research on the QoWL in universities is descriptive with a focus on academic members. As such, opportunities exist for future quantitative and qualitative research in QoWL with a focus on all job categories and other key stakeholders. Influences on improved QoWL construct only demarcate into a particular portfolio (Human Resources), overlooking other portfolios and external influences that can have a positive effect on improved QoWL of employees with associated benefits.

\section{Competing Interests Statement}

The author declares that there are no competing or potential conflicts of interest.

\section{References}

Aketch, J. R., Odera, O, Chepkuto, P., \& Okaka, O. (2012). Effects of self-sponsored programs on academic staff performance at Kenyan Universities. International Journal of Humanities and Social Science, 2(15), 60-64.

Arif, S., \& Ilyas, M. (2013). Quality of work-life model for teachers of private universities in Pakistan. Quality Assurance in Education, 21(3), 282-298. https://doi.org/10.1108/QAE-Feb-2012-0006

Armstrong M. (2006). A handbook of human resource management practice (10th ed., p. 264). Kogan Page Publishing.

Ballou, B., Norman, H., \& Goodwin, N. (2007). Quality of Work Life. Strategic Finance, 89(4), 41-45.

Beukema, L. (1987). Kwaliteit Van De Arbeidstijdverkorting [Quality of reduction of working hours]. Groningen: Karstapel". In: Suzanne, E. J. Arts, Ada Kerkstra, Jouke Van Der Zee, and Huda Huyer Abu Saad, (eds.) (2001). Quality of Working Life and Workload in Home Help Services: A Review of the Literature and a Proposal for a Research Model. Scandinavian Journal of Caring Society, 15, 12-24.

Bhavani, M., \& Jegadeeshwaran, M. (2014). Job Satisfaction and Quality of Work Life-A Case Study of Women Teachers in Higher Education. SDMIMD Journal of Management, 5(2), 1-12. https://doi.org/10.18311/sdmimd/2014/2661

Boas, A. A. V. and Morin, E. M. (2013). Quality of working life in public higher education institutions: the 
perception of Brazilian and Canadian professors. International Journal of Business and Social Science, 4(12).

Buffardi, L., Baughman, K., \& Morse, K., (2004). Findings from the 2003 Quality of Work Life Survey of George Mason University Employees (Draft Report).

Daud, N. (2012). The Influence of Quality of Work Life on Organizational Commitment: A Study on Academic Staff in Public Institution of Higher Learning in Malaysia. International Conference on Innovation, Management and Technology Research, 673-678. https://doi.org/10.1109/ICIMTR.2012.6236480

Davis, L. E. \& Cherns, A. B. (1975). (Eds). The Quality of Working Life (Vol 1. Problems, Prospects, and the State of the Art). New York, USA, Free Press.

Des Jarlais, C. D. (1995). Determinants of faculty morale in an American public re- search university: Gender differences within and between academic departments (Un- published doctoral dissertation, University of Hawai'i at Manoa).

Dolan, S. L., Garcia, S., Cabezas, C., \& Tzafrir, S. S. (2008). Predictors of Quality of Work and Poor Health among Primary Health care Personnel in Catalonia. International Journal of Health Care Quality Assurance, 21(2), 203-218. https://doi.org/10.1108/09526860810859058

European Foundation for the Improvement of Living Conditions. (2002). New Work organization, working conditions and quality of work: towards the flexible firm? [Online] European Foundation for the Improvement of Living and Working Condition. Luxembourg: Office for official publications of the European Communities: Ireland. Retrieved from www.eurofound.eu.int

Farid, H., Izadi, Z., Ismail, I. A., \& Alipour, F. (2015). Relationship between quality of work life and organizational commitment among lecturers in a Malaysian public research university. The Social Science Journal, 52(1), 54-61. https://doi.org/10.1016/j.soscij.2014.09.003

Hackman, J. R., \& Oldham, G. R. (1980). Work Redesign. Reading, M.A: Addison-Wesley.

Hans, A., Mubeen, S. A., Mishra, N., \& Al-Badi, A. H. H. (2015). A study on occupational stress and quality of work life (QWL) in private colleges of oman (Muscat). Global Business and Management Research, 7(3), 55.

Idris, K. B., Samah, B. B. A., Wahat, N. W. B. A., \& Parsa, P. (2014). Relationship between quality of work life and career advancement among Iranian academics. Procedia-Social and Behavioral Sciences, 152, 108-111. https://doi.org/10.1016/j.sbspro.2014.09.164

Jayakumar, A., \& Kalaiselvi, K. (2012). Quality of Work Life-An Overview. International Journal of MarketingFinancial Services \& Management Research, 1, 34-39.

Johnsrud, L. K. (1996). Maintaining Morale: A Guide to Assessing the Morale of Midlevel Administrators and Faculty. Washington, DC: College and University Personnel Association.

Johnsrud, L.K. (2002). Measuring the Quality of Faculty and Administrative Worklife: Implications for College and University Campuses. Research in Higher Education, 43(3), 379-395. https://doi.org/10.1023/A:1014845218989

Kaur, K., \& Sharma, D. (2016). Perceptions of university teachers with regard to factors determining Quality of Work Life. MMU Journal of Management \& Technology, 1(1), 9-18.

Kermansaravi, F., Navidian, A., Rigi, N. S. \& Yaghoubinia, F. (2015). The Relationship Between Quality of Work Life and Job Satisfaction of Faculty Members in Zahedan University of Medical Sciences. Global Journal of Health Science, 7(2), 228-234. https://doi.org/10.5539/gjhs.v7n2p228

Ketchum, L. D., \& Trist, E. (1992). All teams are not created equal: how employee empowerment really works. Newbury Park: Sage.

Khan, M. T., Ara, N., \& Bhat, S. A. (2016). Reflections and Contemporary Experiences of Quality of Work Life and Performance in Higher Education. International Journal, 9.

Khorsandi, M., Jahani, F., Rafie, M., \& Farazi, A. (2010). Health -Related quality of life in staff and hospital personnel of arak university of Medical sciences in 2009. Journal of Arak Medical University, 13(1), 40-48.

Kumar, H., \& Shanubhogue, A. (1996). Quality of Work Life-An Empirical Approach. Manpower Journal, 32(3), 17-32.

Lawler, E. E. L. L. L. (1982). Strategies for Improving the Quality of Work Life. American Psychologist, 37, 486-693. https://doi.org/10.1037/0003-066X.37.5.486 
Levine, M. F. (1983). Self-developed QWL measures. Journal of Occupational Behavior, 4(1), 35-46.

Mensah, A. O., \& Lebbaeus, A. (2013). The influence of employees' self-efficacy on their quality of work life: The case of Cape Coast, Ghana. International Journal of Business and Social Science, 4(2).

Mirkamali, S., \& Sani, F. N. (2008). A study on the Relationship between the Quality of work life and Job Satisfaction among the Faculty Members of Tehran and Sharif University of Technology. Journal of Research and Planning in Higher Education, 48(1), 73-96.

Mirkamali, S. M. \& Sani, N. F. (2008). A study on the relationship between the quality of work life and job satisfaction among the faculty members of the university of Tehran and Sharif University of technology. Quarterly Journal of Research and planning in higher Education, 14(2), 71-101.

Mirkamalia, S. M., \& Thanib, F. N. (2011). A Study on the Quality of Work Life (QWL) among faculty members of University of Tehran(UT) and Sharif university of Technology (SUT). Procedia - Social and Behavioural Sciences, 29, 179-187. https://doi.org/10.1016/j.sbspro.2011.11.223

Mohammad, A., Ahmad, M.S.A. and Reza, A.A. (2013). The relationship between quality of work life and faculty members' productivity in Islamic Azad Universities in district 4 of Iran. European Journal of Experimental Biology, 3(1), 443-448.

Mohan, K. P., \& Suppareakchaisakul, N. (2014). Psychosocial Correlates of the Quality of Work Life among University Teachers in Thailand and Malaysia. International Journal of Behavioral Science, 9(2), 1-16.

Muindi, F., \& K'Obonyo, P. (2015). Quality of work life, personality, job satisfaction, competence, and job performance: A critical review of literature. European Scientific Journal, ESJ, 11(26).

Nanjundeswaraswamy, T. S., \& Swamy, D. R. (2013). Quality of worklife of employees in private technical institutions. International journal for quality research, 7(3).

Ngcamu, B. S., \& Letooane, M. K. (2015a). An exploratory Study on factors affecting the Quality of Work Life in a university in South Africa. Proceedings of the 2015 Seventeenth Annual international conference Global Business and Technology Management Association: Exploring the Possibilities for Sustainable Future Growth in Business and for Sustainable Future in Business and Technology Management, 7-11 July 2015, Peniche/Lisbon, Portugal. 1-7. (Accredited).

Ngcamu, B. S., \& Letooane, M.K. (2015b). Job satisfaction and well-being in a university in South Africa: A Quality of Work Life context. Proceedings of the 2015 Conference Pan Pacific Conference XXXII: Innovation in SOEs in the Digital Age, 1-3 June 2015, Hanoi, Vietnam: 309-311.

Ogunsanya, O. V. (2012). Decision Support using Bayesian Networks for Clinical Decision Making (Doctoral dissertation, Queen Mary University of London).

Pandey, A., \& Jha, B. K. (2014). Review and Redefine: Quality of Work Life for Higher Education. Global Journal of Management and Business Research: A Administration and Management, 14(11), 34-41.

Parsa, B., Idris, K.B., Samah, B.B.A., Wahat, N.W.B.A. and Parsa, P. (2014). Relationship between quality of work life and career advancement among Iranian academics. Procedia-Social and Behavioral Sciences, 152 , pp.108-111. https://doi.org/10.1016/j.sbspro.2014.09.164

Punia, V., \& Kamboj, M. (2013). Quality of Work-life Balance Among Teachers in Higher Education Institutions. Learning Community, 4(3), 197-208. https://doi.org/10.5958/j.2231-458X.4.3.010

Rethinam, G., \& Ismail, M. (2008). Constructs of Quality of Work Life: A Perspective of Information and Technology Professionals. European Journal of Social Sciences. 7(1), 58.

Rethinam, G. S. (2008). Constructs of Quality of Work Life: A Perspective of Information and Technology Professionals. European Journal of Social Sciences, 7(1), 58-70.

Reyan, G. M. (1995), Theoretical basic for the QWL concept. University of Siena: quality (esprit project 8162) 9 working paper).

Royuela, V., López-Tamayo J. \& Suri-ach, J. (2008). The institutional vs. the academic definition of the quality of work life. What is the focus of the European Commission? Social Indicators Research, 86(3), 401-415. https://doi.org/10.1007/s11205-007-9175-6

Saeed, K., \& Farooqi, Y.A. (2014). Examining the Relationship between Work Life Balance, Job Stress and Job Satisfaction Among University Teachers (A Case of University of Gujrat). International Journal of Multidisciplinary Sciences and Engineering, 5(6), 9-15. 
Serey, T. T. (2006). Choosing a robust quality of work life. Business Forum, 27(2), 7-10.

Shahbazi, B., Shokrzadeh, S., Bejani, H., Malekinia, E., \& Ghoroneh, D., (2011). A survey of relationship between the quality of work life and performance of Department Chairpersons of Esfahan University and Esfahan Medical Science University. Procedia-Social and Behavioral Sciences, 30, 1555-1560. https://doi.org/10.1016/j.sbspro.2011.10.302

Singh, O. P., \& Singh, K. S. (2015). Quality of Work Life of Teachers Working in Higher Educational Institutions: A Strategic Approach towards Teacher's Excellence. International Journal of Advance Research in Computer Science and Management Studies, 3(9), 180-186.

Sirgy, M. J., Efraty, D., Siegel, P., \& Lee, D. J., (2001). A new measure of quality of work life (QWL) based on need satisfaction and spillover theories. Social indicators research, 55(3), 241-302. https://doi.org/10.1023/A:1010986923468

Soltanzadeh, V., Ghalvandy, H., \& Fatahy, M. (2012). A Study of the Relationship between the Quality of Work Life and Job Satisfaction among the Faculty Members of Shiraz University. Journal of Human Resource Management Researches, 4(2), 125-149.

Tabassum, A. (2012). Interrelations between Quality of Work Life Dimensions and Faculty Member Job Satisfaction in the Private Universities of Bangladesh. European Journal of Business and Management, 78-89.

Tamjidi, A. (2007). Evaluate the Quality of Working Life and Relationship Managers Performance Roodsar City State Schools (MA thesis, Tehran: Allameh TABAEI Tba. School of Psychology and Educational Sciences, p. 28).

Vilas Boad, A. A., \& Morin, E. M. (2013). Quality of Work Life in Public Higher Education Institutions: The perception of Brazilian and Canadian professors. International Journal of Business and Social Science, 4(12), 67-77.

Walton, R. (1973). Quality of Work life Indicators-Prospects and Problems: A Portigal Measuring the Quality of working life (pp.57-70). Ottawa.

Walton, R. E. (1974). QWL indicators: prospects and problems. In Portigal, A. H. (Eds.). Measuring the quality of working life. A symposium on Social Indicators of Working Life. Ottawa, March, 19-20.

Walton, R. E. (1975). Criteria for quality of working life. In Davis, L.E., Cherns, A.B. and Associates (Eds.), The quality of working life, the free press (pp. 91-104). New York: NY.

WFD Consulting. (2003). The Ohio State University Faculty Work Environment and Work/Life Quality Report Executive Summary. Retrieved 20 April, 2017, from Staff Professional Development and Work/Life Survey Report. http://senate.osu.edu/WorkLife ExecSummary.pdf

Winter, R., Sarros, J., \& Tanewski, G. (1998). Quality of Work Life of Academics in Australian universities: A Pilot study (Working Paper 58/98).

Yavari, U., Tash, A., \& Tondnevis, F. (2009). Compare the quality of working life and its subscales in the faculty of physical education colleges and public universities. Journal of Movement and Exercise Science, 7(1), 99-109.

Zabrodska, K., Mudrak, J., Kveton, P., Blatný, M., Machovcova, K., \& Solcova, I. (2016). Keeping marketisation at bay: The quality of academic worklife in Czech universities. Sociologicky Casopis, 52(3), 347. https://doi.org/10.13060/00380288.2016.52.3.262

\section{Copyrights}

Copyright for this article is retained by the author(s), with first publication rights granted to the journal.

This is an open-access article distributed under the terms and conditions of the Creative Commons Attribution license (http://creativecommons.org/licenses/by/4.0/). 